\title{
The Politics of Insecurity in the Arab World: A View from Beirut
}

\author{
Waleed Hazbun, American University of Beirut
}

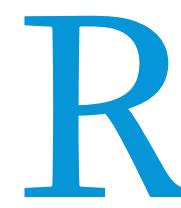
obert W. Cox famously observed that "theory is always for someone and for some purpose. There is...no such thing as theory in itself divorced from a standpoint in time and space" $(1986,207)$. International relations (IR) scholarship on the Middle East is no exception. IR and security studies scholarship since the US invasion of Iraq and throughout the Arab uprisings generally has been framed around questions that relate to the security interests and policies of the US and its allies. This has left Western IR scholarship detached from the challenges, threats, and interests of the people in the region. For IR theory to be relevant to the peoples of the Middle East, Bilgin $(2015,10)$ highlights the need "to understand insecurities experienced by various states and non-state actors in the Arab world." What insights into understanding and theorizing the politics of security in the Arab region can be gained from a vantage point located inside the region, such as the once war-torn city of Beirut?

Taking seriously the experience of such so-called weak and insecure states points to an approach toward understanding the geopolitics of the Arab world that recognizes the heterogeneous nature of the security environment composed of diverse state, non-state, and transnational actors that serve as agents of both security and insecurity. The security calculations of these actors also must be understood as embedded in transnational security relationships. Lebanon, for example, often is viewed as the quintessential weak state, with this weakness defined as a source of political instability and regional insecurity. A closer look at Lebanon's “weak" but plural system of governance over security, however, suggests that it has been relatively effective and surprisingly resilient in containing both domestic and external security threats. Lebanon should not be dismissed as an exceptional case. Instead, it offers a largely ignored context from which to develop new theoretical perspectives about how to promote security for peoples and states in the region.

\section{MAPPING THE POLITICS OF INSECURITY IN THE ARAB WORLD: BEYOND THE STATE}

The Lebanese scholar Bassel Salloukh $(2015,47)$ referred to a so-called Montréal school of Arab politics that emphasizes "the overlap between domestic, transnational and geopolitical factors in the making of Middle East international relations." Salloukh and his colleagues identify the permeability of Arab states and national political systems to transnational ideological currents as well as non-state actors that challenge regime legitimacy and security. This approach suggests a path for IR theorizing based on recognizing the agency of domestic and non-state actors in the context of a region of states weakened by war and external intervention (Salloukh 2015, 50).

In doing so, one must avoid the parochialisms noted by Pinar Bilgin (2015) in which particular questions of security are defined in terms of the idealized Weberian "nation-state." At the same time, one should not represent the Middle East as an exceptional region that requires its own particular theorizations. A "Beirut School" of IR would also need to develop a transnational approach that recognizes how internal state and security structures have been produced by and embedded in global structures.

Across the Arab world, societal actors often understand the sources of insecurity they face in ways that differ from those of Arab state elites and political regimes. This is due in large part to the way that the region became integrated into global political and economic structures (Niva 1999). This disjuncture is a long-standing product of patterns of state-building in which regimes gain security directly from external powers and/or gain needed arms and resources from rentier sources (e.g., oil receipts and foreign aid). This process short-circuits European-style state-building as understood by Charles Tilly (1990), in which rulers provide security for their societies in exchange for the ability to extract the needed resources and labor to promote it. In contrast, state elites across the Arab world often define their interests in relation to external patrons rather than to their own societies, whereas societal groups often view external forces, rival societal groups, or even the state as primary security threats.

Throughout the 1950 os and 1960s, for example, conflicts between regime and societal understandings of insecurity were defined by the rise of radical-populist Arab nationalism, which sought to challenge the role of Western powers in Arab regional politics (Ajami 1978; Kerr 1971). The mobilization of Arab nationalist forces compelled some states to follow Arabist policies even when they challenged the regime's own interests, often tied to their external patrons. By the 1970s, the consolidation of state power and the suppression of dissenting social forces resulted in foreign policies more reflective of regime preferences, often tied to the security interests of external powers. However, new disjunctures between societal groups and regimes about the understanding of insecurity arose by the 1990 . The US invasion of Iraq in 2003 and the rise of Iranian regional influence further fragmented political order in Arab states. These disjunctures drove the Arab uprisings and their subsequent slide into civil war (Hazbun 2015). Seeking to account for them and explain their implications is a central task for scholars of security politics in the Arab world. An exploration of 
the case of Lebanon provides a useful example of a state torn by similar conflicting understandings of insecurity but managing-for the time being-to avoid civil war.

\section{SECURITY AS AN ASSEMBLAGE: THE CASE OF LEBANON}

The small eastern Mediterranean state of Lebanon has gained little notice from US political science scholars interested in but rather are subject to political construction and fluid, shifting patterns of alliances with domestic and external forces (Hazbun 2016). I focus on the struggle between rival politicalsecurity alignments formed in the wake of the 2005 assassination of former Lebanese Prime Minister Rafiq Hariri. I show how the anti-Syrian forces that coalesced in 2005 attempted to promote their vision of a Lebanon free from Syrian control

\section{In doing so, one must avoid the parochialisms noted by Pinar Bilgin (2015) in which particular questions of security are defined in terms of the idealized Weberian "nation-state." At the same time, one should not represent the Middle East as an exceptional region that requires its own particular theorizations.}

the Arab uprisings. Lacking a highly centralized authoritarian regime to be challenged by a popular uprising, Lebanon failed to fit into the framework used by comparative politics to study the Arab world. Meanwhile, in IR, Lebanon has long been viewed as a weak state debilitated by sectarian conflict, serving as a geopolitical battleground for foreign powers and their local proxies. These conditions are assumed to foster the proliferation of violent non-state actors that generate political instability and insecurity for their neighbors. As a result, security studies scholarship on Lebanon tends to focus on militant groups such as Hizballah (and how to contain them) and/or suggest that Lebanon's primary security interest must be to centralize and expand the coercive powers of the Lebanese state. As the uprisings in Yemen, Libya, and Syria were followed by armed intervention from regional powers, these territories were led into civil wars that for most external observers overshadowed developments in Lebanon. To the degree that Lebanon appears in discussions of the post-uprisings Arab world, it is as one of the zones of refugee flows and humanitarian crisis-or, sometimes, referenced to as the "Lebanesemodel" for sectarian-based power-sharing agreements.

Contrary to these representations, Lebanon's plural system of governance over security has been relatively effective and surprisingly resilient in containing both domestic and external security threats. The effectiveness of the Lebanese security system is not due primarily to its consociational system for sectarian-based political representation or enhanced by efforts to build strong, autonomous state institutions. Rather, my observations suggest that the current Lebanese security system operates as an assemblage of conflicting state and non-state actors that constantly negotiate among rival understandings of insecurity. It is largely these dynamics of competition and accommodation in which no one party is able to attain hegemony and eliminate its rivals that defines the resilience of the Lebanese security system. This relative and fragile success stands in contrast to the failures of other national security systems across the region in which a ruling elite seeks to impose its dominance.

Elsewhere, I provide a mapping of the development of the contending discourses of insecurity in Lebanon, highlighting how they are not reducible to primordial sectarian identities and with Hizballah disarmed. However, even with external backing from Western and Arab Gulf states, they could not institutionalize their preferences. In the wake of the 2006 war with Israel and with Iranian backing, Hizballah expanded its political leverage-at times wielding violence against rival militias and political forces. It was able to succeed in its approach to Lebanese security, which focused on "resistance" to Israel, and eventually was institutionalized within the doctrine and practices of the Lebanese state, including the army. However, with growing domestic tensions created by the Syrian uprising and civil war that sharply divided the Lebanese sides, President Michael Sleiman-the former commander of the army-sought in June 2012 to limit the impact of the war on Lebanon by creating through National Dialogue meetings a collective statement. It is known as the Baabda Declaration, which outlined a policy of "disassociation" from the conflict.

By 2013, however, Hizballah's increasing engagement in the Syrian civil war violated this collective understanding (which it declared "stillborn"), leading to the partial unraveling of Lebanon's broader security understandings. However, as the regional threat of Islamic State and other militant groups became a common concern of rival parties in Lebanon, increased security cooperation among these rival parties, domestic security forces, and foreign intelligence agencies contained the domestic and external threats-even as the parties remained deeply divided about the civil war in Syria. Meanwhile, Hizballah's expansive military role in both Lebanon and Syria mobilized Lebanese and foreign jihadists and led to a radicalization of elements of Lebanese Sunni political forces. This left Lebanese politics highly fractured and making any national consensus on national security policy even less likely (on the spillover effects of the Syrian war, see Salloukh 2017).

Although external patrons and regional sectarian-based conflicts clearly shape the course of security politics in Lebanon, a framework reduced to the rivalry of external states cannot fully explain how Lebanese actors have been able to negotiate among rival understandings and produce sharedalbeit highly contingent-understandings of how to address security threats, which this assemblage approach to security attempts to do. Wrought with tensions, security politics in 
Lebanon requires continual adjustment to avoid collapse and resorting to internal war, as occurred between 1975 and 1990. Another implication of this framework that turns the weakstate approach upside down is that external powers that want to support Lebanon's security would best serve it by trying to enhance the country's ability to support mechanisms that foster the dynamics of pluralism in which tensions among rival understandings of security are constantly defused but possibly never eliminated. security interests, the development of security studies within the Arab world lacks a self-defined normative order to identify sources of insecurity (Barnett 1998). An alternative approach to understanding Arab conceptions of security would unpack the "insecurities experienced by various state and non-state actors in the Arab world, as well as the military, economic, and societal dimensions of insecurity" (Bilgin 2015).

The initiative to promote dialogue about the nature of security across multiple levels of the discipline should include

\section{It is largely these dynamics of competition and accommodation in which no one party is able to attain hegemony and eliminate its rivals that defines the resilience of the Lebanese security system.}

Although this observation of Lebanese security politics remains suggestive and open to correction, it is offered as an illustration of theorizing rival understandings of insecurity found within the Arab world. This interpretation of Lebanon's complex geopolitics of insecurity is not based on an exceptionalist understanding but rather views the country within the context of the political dynamics of the regional Arab system and the heterogeneous security dynamics found in states across the region. In Lebanon, as elsewhere in the region, diverse societal actors often understand insecurity in ways that contrast with the understanding of their own state elites. Even across elites within the same state or regime, different political interests and leaders in state institutions often hold contrasting understandings of sources of insecurity. As a result, security politics in Lebanon-and much of the Arab region-play out among multiple rival actors in configurations that escape accurate representation with the statist bias and state-society binary found in most IR scholarship. engagement with scholars based in the region (see Valbjørn in this issue). Beirut has evolved as a hub for innovative field research, scholarly knowledge production, and institutional development about issues of security in Lebanon and the wider Arab world. Research on security issues in Lebanon has helped to develop concepts and approaches, such as the notion of "hybrid-sovereignty." This research is increasingly relevant to understanding security politics across the Arab world, where non-state and substate actors have come to exercise state-like capacities and authorities (Abboud and Muller 2012; Fregonese 2012). Such scholarship, especially when based on extensive local fieldwork, provides maps of the diverse understandings and lived experiences of insecurity (Fawaz, Harb, and Gharbieh 2012). The research often draws on local readings and counter-discourses to explore the limits of Western-dominated institutions and security regimes over arms control (Hindawi 2011), peacekeeping (Makdisi 2011; Makdisi and Prashad 2016), and crisis management (Kosmatopoulos 2011). A critical contribution of

\section{This interpretation of Lebanon's complex geopolitics of insecurity is not based on an exceptionalist understanding but rather views the country within the context of the political dynamics of the regional Arab system and the heterogeneous security dynamics found in states across the region.}

\section{TOWARD A "BEIRUT SCHOOL" OF SECURITY STUDIES?}

Postcolonial critiques of IR theory argue that "security studies is by and for Western powers" (Barkawi and Laffey 2006, 344). The problem of "security" usually is posed as a question of how to promote a Western-dominated order while ignoring the hierarchical power relations and means of violence deployed to sustain such an order. Local actors, when recognized to have agency, are viewed in terms of how they sustain such an order-or else represent threats to it-but rarely in terms of their own interests and understandings of insecurity (Hazbun 2013). Lacking a regional security order and with many states fragmented among political forces with rival such scholarship is its effort to explore how local conceptions of insecurity are often at odds with those embedded and enforced by the "international community."

Moreover, recent institutional efforts in Beirut seek to build capacity for knowledge production in the field of security studies. Beirut provides scholars and institutions a relatively open intellectual space and the position of hybrid American/Arab institutions, such as the American University of Beirut (AUB), to maintain a cosmopolitan mix of Arab and non-Arab professors and students who establish intellectual communities with multiple local and transnational audiences. At AUB, the Issam Fares Institute for Public Policy 
and International Affairs-an independent policy centerwas founded a decade ago, and an innovative master's program in public policy and international affairs was recently established that specializes in addressing regional security issues, such as the Syrian crisis. Also with headquarters in Beirut, the Arab Council for the Social Sciences was founded with the goal of training scholars in and from the region to produce knowledge relevant to the peoples of the region. An ongoing project involves training and fostering research in critical approaches to security studies (Arab Council for the Social Sciences 2017).

Although these efforts may not result in a coherent approach or a distinct theory of security, together they aspire to engage in global debates bringing in new perspectives and voices in the long-overdue project of making IR more "global." It is only by fostering such scholarship that American IR scholars will be able to find voices with which to engage in transformative dialogues about the Middle East.

\section{REFEREN CES}

Abboud, Samer and Benjamin Muller. 2012. Rethinking Hizballah: Authority, Legitimacy, Violence. London: Ashgate.

Ajami, Fouad. 1978. "The End of Pan-Arabism." Foreign Affairs 57 (2): 355-73.

Arab Council for the Social Sciences. 2017. "The Beirut Forum on Critical Security Studies in the Arab World." Available at www.thebeirutforum.com.

Barkawi, Tarak and Mark Laffey. 2006. "The Postcolonial Moment in Security Studies." Review of International Studies 32 (2): 329-52.

Barnett, Michael N. 1998. Dialogues in Arab Politics: Negotiations in Regional Order. New York: Columbia University Press.

Bilgin, Pinar. 2015. "One Model of Engagement between MES and IR." In International Relations Theory and a Changing Middle East. POMEPS Studies 16, September 17: 6-12.

Cox, Robert W. 1986. "Social Forces, States, and World Orders." In Neorealism and Its Critics, ed. Robert O. Keohane, 204-54. New York: Columbia University Press.
Fawaz, Mona, Mona Harb, and Ahmed Gharbieh. 2012. "Living in Beirut's Security Zones: An Investigation of the Modalities and Practice of Urban Security." City \& Society 24 (2): 105-259.

Fregonese, Sara. 2012. "Beyond the Weak State: Hybrid Sovereignties in Beirut." Environment and Planning D: Society and Space 30 (4): 655-74.

Hazbun, Waleed. 2013. "The Geopolitics of Knowledge and the Challenge of Postcolonial Agency: International Relations, US Policy and the Arab World." In The Oxford Handbook of Postcolonial Studies, ed. Graham Huggan, 217-34. Oxford, UK: Oxford University Press.

. 2015. "A History of Insecurity: From the Arab Uprisings to ISIS." Middle East Policy 22 (3): 55-65.

. 2016. "Assembling Security in a 'Weak State': The Contentious Politics of Plural Governance in Lebanon since 2005." Third World Quarterly 37 (6): 1053-70.

Hindawi, Coralie Pison. 2011. "The Controversial Impact of WMD Coercive Arms Control on International Peace and Security: Lessons from the Iraqi and Iranian Cases." Journal of Conflict \& Security Law 16 (3): 417-42.

Kerr, Malcolm. 1971. The Arab Cold War: Gamal 'Abd al-Nasir and His Rivals, 1958-1970. London: Oxford University Press.

Kosmatopoulos, Nikolas. 2011. "Toward an Anthropology of 'State Failure': Lebanon's Leviathan and Peace Expertise." Social Analysis 55 (3): 115-42.

Makdisi, Karim. 2011. "Constructing Security Council Resolution 1701 for Lebanon in the Shadow of the 'War on Terror." International Peacekeeping 18 (1): 4-20.

Makdisi, Karim and Vijay Prashad (eds.). 2016. Land of the Blue Helmets: The United Nations in the Arab World. Berkeley: University of California Press.

Niva, Steve. 1999. "Contested Sovereignties and Postcolonial Insecurities in the Middle East." In Cultures of Insecurity: States, Communities, and the Production of Danger, eds. Jutta Weldes, Mark Laffey, Hugh Gusterson, and Raymond Duvall, 147-72. Minneapolis: University of Minnesota Press.

Salloukh, Bassel F. 2015. "Overlapping Contests and Middle East International Relations." In International Relations Theory and a Changing Middle East. POMEPS Studies 16, September 17: 47-51.

. 2017. “The Syrian War: Spillover Effects on Lebanon.” Middle East Policy 24 (1) ): 62-78.

Tilly, Charles. 1990. Coercion Capital and European States A.D. 990-199o. Oxford: Blackwell. 